\title{
小児両側骨性前鼻孔閉鎖症の一例
}

\author{
藤田保健衛生大学医学部耳鼻咽喉科学教室 \\ 大山俊廣内藤健晴岩田重信 \\ 岩田義弘 小森 真由美 高須 昭 彦
}

\section{A CASE REPORT OF BILATERAL ANTERIOR NASAL BONY ATRESIA}

\author{
Toshihiro Ohyama, Kensei Naito, Shigenobu Iwata \\ Yoshihiro Iwata, Mayumi Komori and Akihiko Takasu \\ Department of Otolaryngology, Fujita Health University, School of Medicine
}

\begin{abstract}
Anterior nasal atresia is a relatively rare condition that may cause airway obstruction. An 8-weekold newborn male with bilateral anterior nasal bony atresia was treated surgically via a sublabial approach. The stenotic bony apertures were widened using a surgical drill and tracheal tubes (I.D.3.0mm) were placed in each nasal cavity for 4 weeks.

Three years after the operation, no recurrence was found. Fifty cases of anterior nasal atresia, including our case, have been reported in Japan. Only one case of bony stenosis was reported in 1938, and we believe that our patient is the second reported case of anterior nasal bony atresia in Japan.
\end{abstract}

Key words : newborn, nasal obstruction, anterior nasal atresia, nasal bony atresia

\section{1. 緒 言}

前鼻孔閉鎖症は, 本邦においては 1901 年 ${ }^{1)} に$ 佐藤が報 告して以来，現在までに 49 例の報告を見るのみであ $\eta^{2)}$, 先天性または後天性に認められる稀な疾患である。 さらに骨性閉鎖の場合，その報告は現在まで神尾 $(1938)^{3)}$ の 1 例を見るにすぎない。今回我々は，両側骨 性前鼻孔閉鎖症の新生児に対し外科的治療を施行し，術 後良好な経過を得られた症例を経験したので文献的考察 を加え報告する。

\section{2. 症 例}

【症 例】G，S．男児

【主 訴】呼吸困難

【家族歴】特記すべき事項なし。

【現病歴】平成 6 年 6 月 4 日（在胎 35 週 3 日）前早期破 水の後, 自然分婏にて出生。低出生体重児（出生体重
2114g）および新生児仮死にてNICU管理となる。呼吸困 難が認められ，小児科医により気管支拡張剤などの投薬 加療されたが, 症状の改善をみなかった。また哺乳力低 下のため経鼻的に N-Gチューブの挿入を行うも, 非常に 困難を伴って留置された。その時点で前鼻孔の狭窄が疑 われたため, CTを施行したところ前鼻孔の骨性閉鎖(不 完全閉鎖）を認め当科に併診依頼があった。

【全身所見】出生体重2114g（低出生体重児）, 頭位 31. $5 \mathrm{~cm}$, 身長 $46 \mathrm{~cm}$ で, 胸腹部四肢に異常なく, 他の合併奇 形は認めなかった。

【検査所見】血液, 尿検査, 胸部レントゲン写真, 心電 図にて異常は認めず, TPHAは陰性, 母胎内感染あるい は染色体異常は認められなかった。

【局所所見】前鼻鏡所見で，両側の前鼻孔は極めて狭小 化しており,特に右鼻腔は\# 5 の経鼻栄養チューブがやっ と通過する程度の大きさであった(図 1 )。また両鼻孔と も黄色粘膿性鼻汁を認め, 細菌学的検査の結果MRSAが 
検出され抗生剂OFLXの点鼻局所投与を行った。3D-CT 上は両側前鼻孔（とくに右前鼻孔の狭小化が著しい）の 骨性の不完全閉鎖が認められ，両側骨性前鼻孔閉鎖症と 診断した。

【経過】症例はNICU管理下で成長を待ち保存的に前鼻 孔の開大を期待したが，無呼吸発作の頻発と陌没呼吸を 認め，投薬によっても呼吸困難は改善せず，早期の外科 的治療が必要との小児科医による判断によって, 平成 6 年 8 月 5 日全身麻酔下にて両前鼻孔開大術を施行した。 Sublabial excision approachにて狭小化した前鼻孔骨を

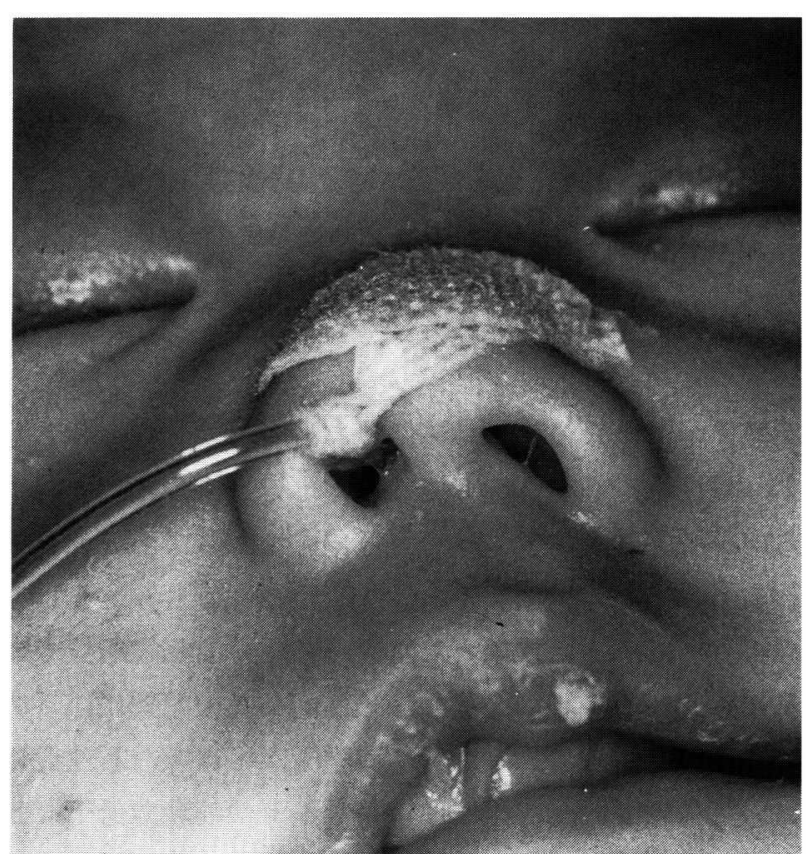

図 1 術前の鼻腔所見

哺乳力低下のため右鼻腔に\# 5 の経鼻栄養チューブ が留置されている。扱入は困難であった。
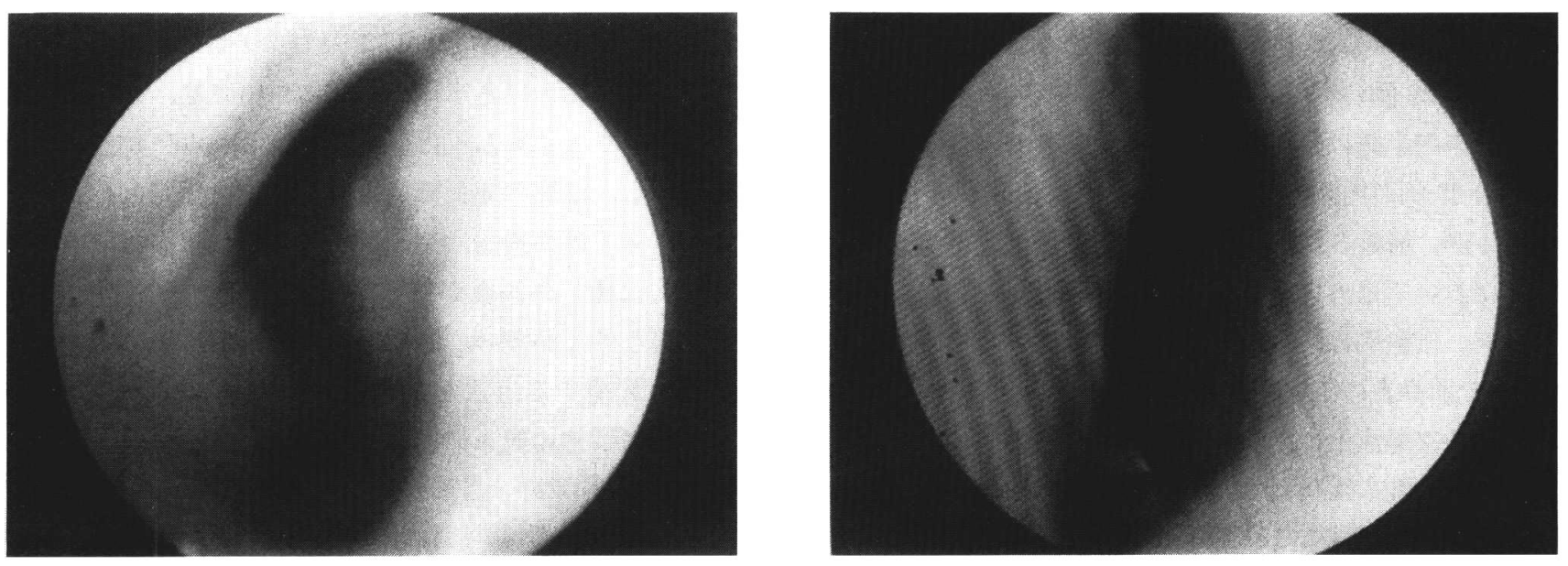

図 3 術後の鼻腔ファイバー所見（退院 2 年 6 力月後）

左に右鼻腔内所見，右に左鼻腔内所見を示す。

露出し，軟部組織を骨面より鼻腔内側に向かって充分剥 離した後, 前鼻孔骨をバーにて内径 $3 \mathrm{~mm}$ のポーテックス チューブが容易に挿入できる程度の大きさに開大した (図 2 )。同サイズのポーテックスチューブを両側鼻腔内 に挿入し術後の再狭窄防止のため約 1 力月間留置した。 MRSAによる術後感染も併発せず前鼻孔の開大により 呼吸状態もほほ正常に回復し哺乳も良好となり, 平成 6 年 9 月 9 日退院した。退院時の体重は $4100 \mathrm{~g}$ であった。そ の後も外来にて 3 年以上経過観察を続けているが全身の 発育も順調で, 現在まで鼻腔内の再狭窄も認めず(図 3 ), 3D-CTでも前鼻孔の開大は充分で良好な経過が得られ ている(図 4)。

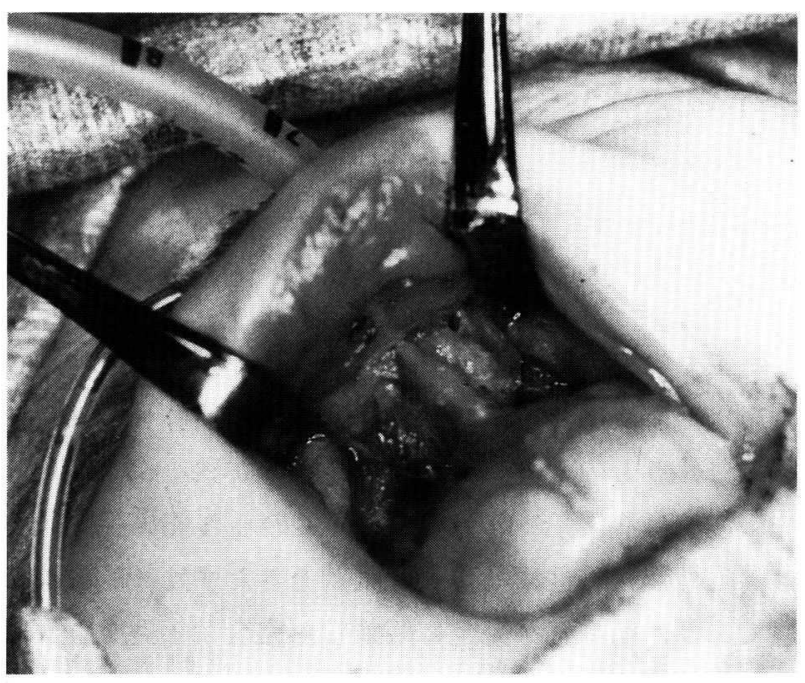

図 2 術中所見

内径 $3 \mathrm{~mm}$ のポーテックスチューブが容易に挿入 できる程度の大きさに開大。 

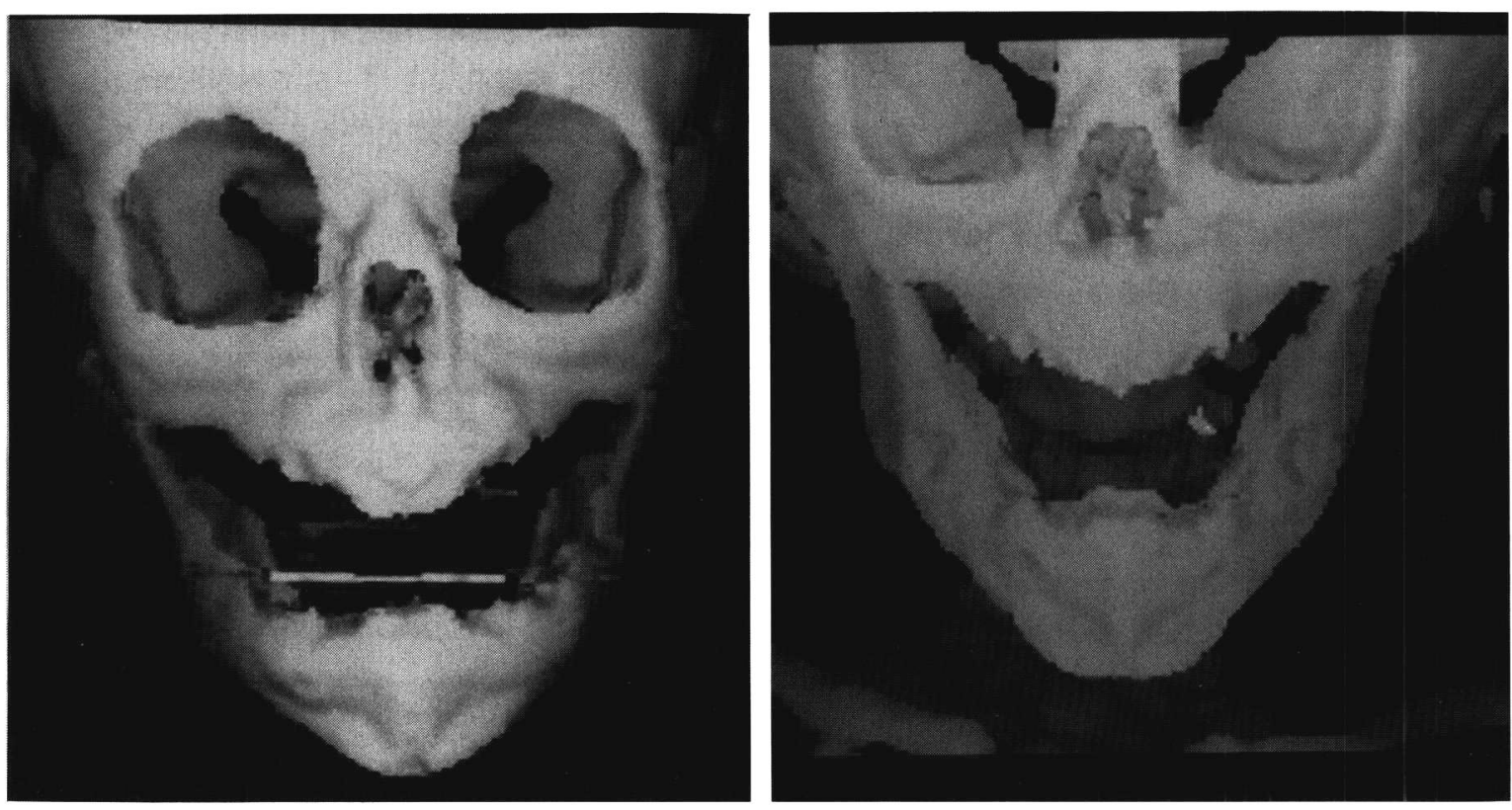

図4 術前後の 3D-CT像（左：術前，右：術後） 左：両側前鼻孔の骨性の不完全閉鎖を認めた。 右：術前にみられた前鼻孔周囲の骨性隆起, 閉鎖部分は術後十分に開大されている。

\section{3. 考 察}

新生児に扔いて出生直後より鼻閉, 呼吸困難, 哺乳障 害をきたす疾患としては, 後鼻孔および前鼻孔の狭窄, 閉鎖に伴うものや固有鼻腔全体の横幅が狭小化している 先天性狭鼻症 ${ }^{4)}$ 等があげられる。このうち前鼻孔閉鎖症 は，膜性及び骨性に前鼻孔の閉鎖をきたす比較的稀な疾 患であり，前鼻孔が完全に閉鎖した完全閉鎖型と一部に 小孔の残存を伴った不完全閉鎖型がある ${ }^{5)}$ 。本邦におけ る本疾患の第 1 例は 1901 年佐藤 $^{1)}$ により報告され, その 後現在まで高山 ${ }^{6)}$ が報告した戦傷による 39 例 (鼻前庭部 24 例，鼻閾部 15 例）を除外すると，自験例を含めて 50 例の報告がある ${ }^{2)}$ 。本症の成因は先天性及び後天性とに 分けられ，本邦報告例では原因記載のない 3 例を除くと 後天性が 39 例 (78\%) と殆どを占め, 先天性は 8 例 (16\%) で, その内半数は先天性梅毒に随伴したものだった。後 天性の 39 例の内訳は外傷性(熱傷含む) 18 例, 痘瘡 9 例, 湿疹 4 例, 梅毒 3 例, 術後性 2 例, その他 3 例であり, 本邦においては外傷や感染症などに続発した報告例が多 かった。自験例は, 遺伝子異常, 母胎内感染を伴わず, CT上で前鼻孔の不完全な骨性閉鎖のみを認めた(いわゆ る先天性狭鼻症とは異なり固有鼻腔全体の狭小化を認め ない）先天性の前鼻孔骨性閉鎖症であったが，本邦報告 50 例のうち 48 例までが膜様及び洀痕性閉鎖であり, 骨 性閉鎖に関しては 1938 年神尾 ${ }^{3)}$ が報告した一部骨性・一 部膜様の先天性梅毒に伴う 1 例に次いで, 自験例は本邦
第 2 例目の極めて珍しい症例であった。欧米においても 本症は比較的稀とされているが，小児（新生児）におけ る前鼻孔閉鎖症の多くは先天性で骨性閉鎖であるという 報告もある7)。本症は前鼻孔が完全に閉鎖するかもしく は小孔を有するのみであるため，多くは前鼻鏡所見で容 易に診断が付く。本疾患の症状は前鼻孔の閉鎖に伴う鼻 閉及び呼吸困難であり, 特に口呼吸が不得意な新生児に おいては呼吸困難が強く，チアノーゼや哺乳力低下など も重要な所見となる。前述の如く本邦では後天性のもの が多く，外傷や感染などの既往も診断上参考になる。し かし，骨性閉鎖の有無についてはCT，特に3D-CTの施 行が有用である。自験例においても呼吸困難を主訴とし， 経鼻栄養チューブの挿入が困難なため前鼻孔閉鎖が疑わ れ，骨性閉鎖症の診断はC T 及び 3D-CTの所見で行っ た。新生児における本症の治療については，まず保存的 にエアーウェイもしくはMcGovern nipple ${ }^{8)}$ などの装具 を留置し, 患児の成長を待ち前鼻孔の自然開大を期待す るが，多くは外科的治療が必要となる。しかし日本人は 欧米人に比し外鼻孔が狭く小さいため ${ }^{9)}$, その形成手術 は困難なことが多い。閉鎖部への外科的アプローチは経 鼻的に到達する方法と歯㓰部より到達する方法とがあ り，前者は主に成人に対して，後者は主に小児に対して

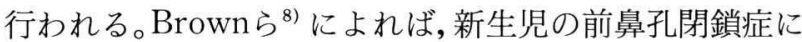
対する適切な手術時期は，患者の状態が許せば体重が 10pounds（約 $4.5 \mathrm{~kg}$ ）以上, 生後 10 週以降, へモグロビ ン $10 \mathrm{~g} / \mathrm{dl}$ 以上になってからが望ましいとしているが，臨 
床的に必要があればそれ以前であっても施行しなければ ならないとしている。自験例では体重 $3.2 \mathrm{~kg}$, 生後 8 週と Brown $^{8)}$ の適応時期に達していなかったが, 呼吸困難 および無呼吸に対して保存加療の限界に達しており,こ のままでは生命予後に関わるとの小児科医の判断のもと 手術に踏み切った。症例は口蓋や前方切歯部分に奇形や 変形を認めなかったが，手術に際しては永久歯原基を損 傷しない範囲で可及的に開大させるよう注意を払った。 また本症は術後容易に再狭窄を来しやすく，その防止の ため鼻内にシリコンチューブなどのステントを留置し, 更にステロイドの内服・局所投与を併用するのが一般的 である。我々も，新生児が充分に鼻呼吸できると思われ る広さが確保できる内腔 $3 \mathrm{~mm}$ のチューブを約一カ月間 留置し, 再発防止に努めたが, 新生児であるためステロ イドの使用は避けた。内藤ら ${ }^{2)}$ の統計によれば術後再発 率は $42 \%$ あ゙り, 本症の術後の経過観察は長期に渡り慎 重に行わなければならない。自験例も術後 3 年以上が経 過し, 現在のところ再狭窄を認めてはいないが, 歯牙お よび上顎洞発育の問題も含めて今後さらに観察を継続す る必要があると思われる。

\section{4. 結 語}

骨性前鼻孔閉鎖症（不完全閉鎖型）の新生児に対し外 科的治療を施行し，術後良好な経過を得られた症例を経 験したので報告した。本邦における前鼻孔閉鎖症の多く は膜性で, 骨性前鼻孔閉鎖症としては 1938 年神尾 ${ }^{3)}$ が報 告した一部骨性，一部膜様の前鼻孔閉鎖症例以来第 2 例 目であった。

本論文の要旨は, 第 34 回日本鼻科学会総会 (平成 7 年 10 月 19 日〜20日，札幌）においてロ演した。

\section{参考文献}

1）佐藤敏夫：前鼻孔癒着ノ一例. 大日耳鼻 7 ： $455-462,1901$

2 ) 内藤健晴, 三輪正人, 岩田重信, 他：前鼻孔閉鎖治 験例.耳鼻臨床 84：1715-1722, 1991

3) 神尾友彦: 両側前鼻孔閉鎖症. 大日耳鼻 44 : 1485-1486, 1938

4 ）古賀慶次郎, 川城信子, 土橋信明, 他：先天性狭鼻 症 新しい疾患概念とその症例.日耳鼻 96 ： 1869-1877, 1993

5 ）石神 寛：前鼻孔閉鎖症二就イテ. 愛知医学 42 ： 301-308, 1935

6 ) 高山七百珠：戦傷による鼻内癒着症の臨床的観察. 大日耳鼻 $49 ： 178-190,1942$

$7)$ Peer LA : Atresia of the anterior nares. Otolaryngology vol III, Chapter 4, Harper \& Row Publishers, 1972, pp 13-15

8 ) Brown OE, Myer CM, Manning SC: Congenital nasal pyriform aperture stenosis. Laryngoscope 99: 86-91, 1989.

9) Ohki M, Naito K, Cole P : Dimensions and resistances of the human nose. Racial differences. Laryngoscope 101 : 276-278, 1991

（1998 年 8 月 27 日受稿， 1998 年 11 月 6 日受理） 別刷請求先 $\bar{\top} 470-1101$

愛知県豊明市沓掛町田楽ヶ窪 1-98 藤田保健衛生大学医学部耳鼻咽喉科学教室 大山 俊廣 